\author{
Yu.V. Naydich, I.I. Gab, T.V. Stetsyuk, B.D. Kostyuk, D.B. Shakhnin ${ }^{1}$
}

\title{
Kinetics of Fragmentation During Annealing in Vacuum of Titanium Nanofilms Deposited Onto Non-Metallic Materials
}

\author{
I.M. Frantsevich Institute for Problems of Materials Science of the NAS of Ukraine, 3 Krzhyzhanovsky St., \\ 03142 Kyiv, Ukraine; e-mail: gab@ipms.kiev.ua \\ ${ }^{I}$ V.I. Vernadsky Institute of General and Inorganic Chemistry of the NAS of Ukraine,32/34 Palladin Ave., \\ 03142 Kyiv, Ukraine; e-mail: shakhnin@ukr.net
}

\begin{abstract}
The results are presented of the study of kinetics of fragmentation of titanium nanofilms $100 \mathrm{~nm}$ thick deposited onto the surface of samples made from single crystals of $\mathrm{Al}_{2} \mathrm{O}_{3}$ (leucosapphire), $\mathrm{ZrO}_{2}, \mathrm{SiC}$, and $\mathrm{AlN}$ ceramics and annealed in vacuum at temperatures $1300 \div 1600{ }^{\circ} \mathrm{C}$ with different exposition times at each temperature within 2 - 20 min range.
\end{abstract}

Keywords: kinetics, fragmentation, titanium nanofilm, single crystal, leucosapphire, ceramics

Стаття поступила до редакиії19.04.2017; прийнята до друку 05.06.2017.

\section{Introduction}

Joining ceramics and other non-metal materials with metals using solder and metal deformable gaskets is widely used in modern technology. For such joints making, thin metal films are often used widely applicable in various fields of science and technology.

The thickness of films deposited onto metallic and non-metallic materials may be within a wide range: from a few nanometers till tens of microns. For technological purposes, metal films are often used with different thicknesses deposited by various methods (plasma sputtering, magnetron sputtering, chemical and electrochemical methods, electron beam sputtering etc.) onto non-metallic parts to join them with each other or with metals by brazing or pressure welding [1 -6].

A special role in joining such different materials are played by adhesively-active metals including titanium, zirconium, niobium, hafnium, and others. These metals are either added to metallic solders composition or used as coatings, particularly in the form of thin films at the surfaces of joined materials; and using pressure welding joints of different materials may be obtained through deformable gaskets made of these metals. These metals have good adhesion to both non-metallic and metallic materials and provide good spreading of metal solders and their interaction at the interface "solder - hard surface to be joined".

Since, during the process of brazing or pressure welding, metalized non-metallic parts must be heated to very high temperatures $\left(1300-1600{ }^{\circ} \mathrm{C}\right)$, studying processes of fragmentation-coagulation occuring during the annealing of these metal nanofilms is not only of cognitive interest, but also of practical importance for the development of technological modes of joining nonmetallic materials.

We have previously studied the kinetics of the fragmentation during annealing in vacuum of niobium and hafnium nanofilms deposited onto oxide and nonoxide non-metallic materials such as sapphire, ceramics based on $\mathrm{ZrO}_{2}$, and others.[7, 8].

The aim of this work was to study the kinetics of fragmentation during the annealing of titanium nanofilms deposited onto some oxide and non-oxide materials.

\section{Materials and Experimental Procedure}

Titanium nanofilm $100 \mathrm{~nm}$ thick was deposited onto non-metallic substrates $4 \times 4 \times 1 \mathrm{~mm}$ made of leucosapphire (single crystal alumina), zirconium dioxide and silicon carbide single crystals, as well as of aluminium nitride ceramics, by electron beam sputtering method [9]. Substrates were made of materials which are either the most widely used in industry, particularly leucosapphire, or the matrix of high-temperature ceramics. Metallic films were deposited onto polished surfaces of substrates. The parameter of surface roughness $R_{z}$ was equal to $0.03 \div 0.05$ microns. 
The polished substrates surfaces were degreased by acetone and ethanol, after which the leucosapphire and zirconium dioxide substrates were annealed in air at 1200 ${ }^{\circ} \mathrm{C}$ for two hours, and then these substrates, together with the substrates made of single crystal silicon carbide and aluminium nitride ceramics, were annealed in vacuum not worse than $2 \times 10^{-3} \mathrm{~Pa}$ at the same temperature for one hour.The $100 \mathrm{~nm}$ thickness of the metal nanofilms was chosen taking into account the fact that such films are solid, completely covering the oxide surface, have good adhesion to it, and provide good solder spreading [10]. Thicker films have the ability to exfoliate due to the presence in them of residual stresses as a result of growth tensions occurrence during the multilayer deposition and because of the large difference between thermal coefficients of linear expansion (TCLE) of film metal and substrate material. Films were deposited during $10-15 \mathrm{~min}$. onto the substrates which temperature was about $100^{\circ} \mathrm{C}$, and the films thickness was determined using a special device with the quartz sensor.

Films were deposited onto all substrates under the same conditions, and their quality was monitored by metallographic microscope XJL-17.

Annealing of non-metallic samples coated by metal films was performed in a vacuum chamber during various time periods from 2 up to $20 \mathrm{~min}$. at different temperatures $\left(1200 \div 1600^{\circ} \mathrm{C}\right)$ in vacuum not worse than $2 \times 10^{-3} \mathrm{~Pa}$.

Annealed samples were examined using scanning electron microscopes JCM-6700, JCM-5000, and an atomic force microscope Nano Scope III a with micrographs recording.

Using these micrographs the area of substrate surface coated with metal film islands was calculated by planimetric weighting method, i.e. by weighting of metal-coated sample parts images cut from micrographs [2]. The data obtained by this method were analyzed as the dependence of sample surface area covered with metal film fragments after annealing on annealing parameters (annealing temperature and time).

\section{Results and Discussion}

Original titanium films on all substrates were solid, without any significant defects, and micrographs obtained using electronic scanning microscopes show only the uniform dark gray field.

During annealing of titanium film on the leucosapphire surface, at first, minor signs of changes in the structure of the film appeared only as a result of its two-minute heating up to $1300^{\circ} \mathrm{C}$. As a result of further exposition at this temperature for five minutes, film began to blister in part without losing its integrity, and the process rate is slightly increased after a ten-minutes annealing (Fig.1a), but the film still remained solid. With increased exposition time up to $20 \mathrm{~min}$ at $1300^{\circ} \mathrm{C}$, the film is rapidly disintegrated into large pieces. The similar pattern was observed with increase of annealing temperature up to $1400^{\circ} \mathrm{C}$ : the film is partially started to blister after the two-minute exposition without losing its integrity; after a five-minute annealing process greatly intensified and the film even started to crack (Fig.1b).

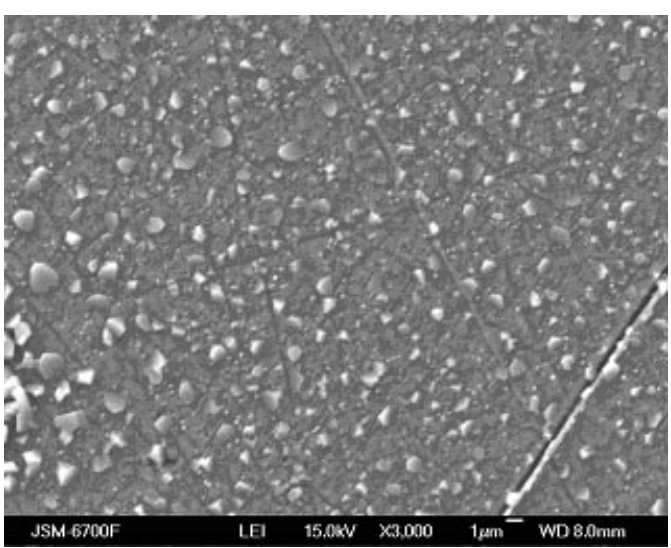

$\mathbf{a}$

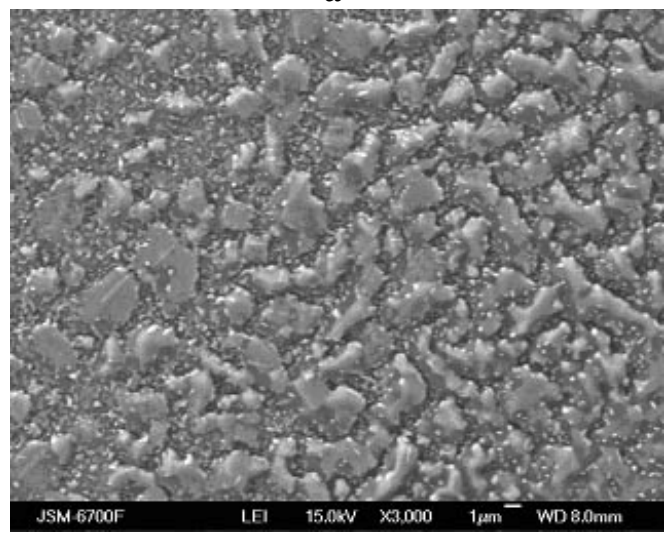

b

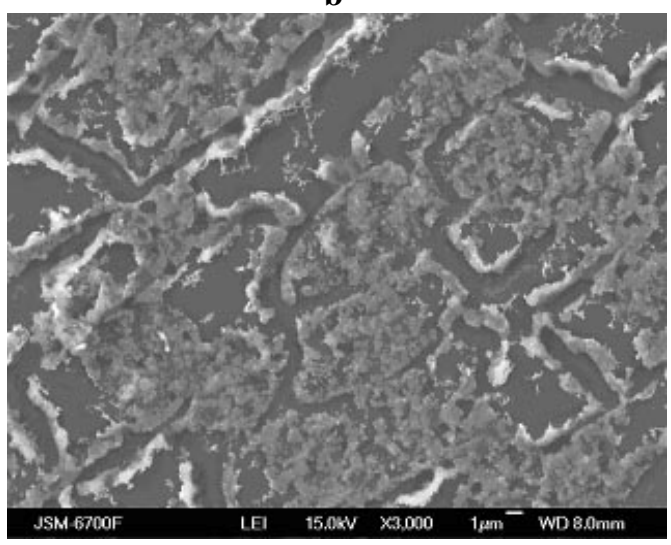

C

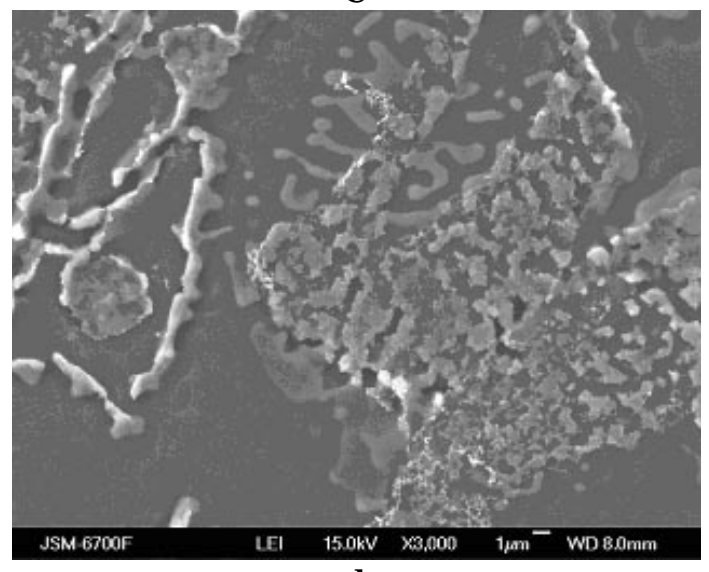

d

Fig. 1. SEM image titanium film $100 \mathrm{~nm}$ thickness onto leucosapphire which was annealed in vacuum, x3000: $\mathrm{a}-1300{ }^{\circ} \mathrm{C}, 10 \mathrm{~min} ; \mathrm{b}-1400^{\circ} \mathrm{C}, 5 \mathrm{~min}$; c $1500{ }^{\circ} \mathrm{C}, 10 \mathrm{~min} ; \mathrm{d}-1500^{\circ} \mathrm{C}, 20 \mathrm{~min}$. 


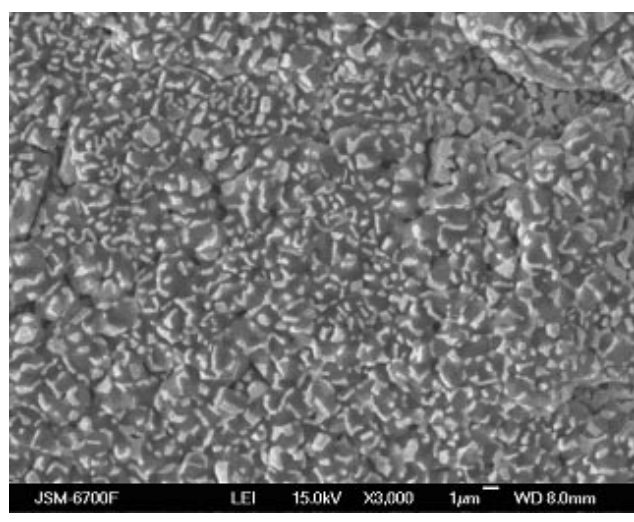

$\mathbf{a}$

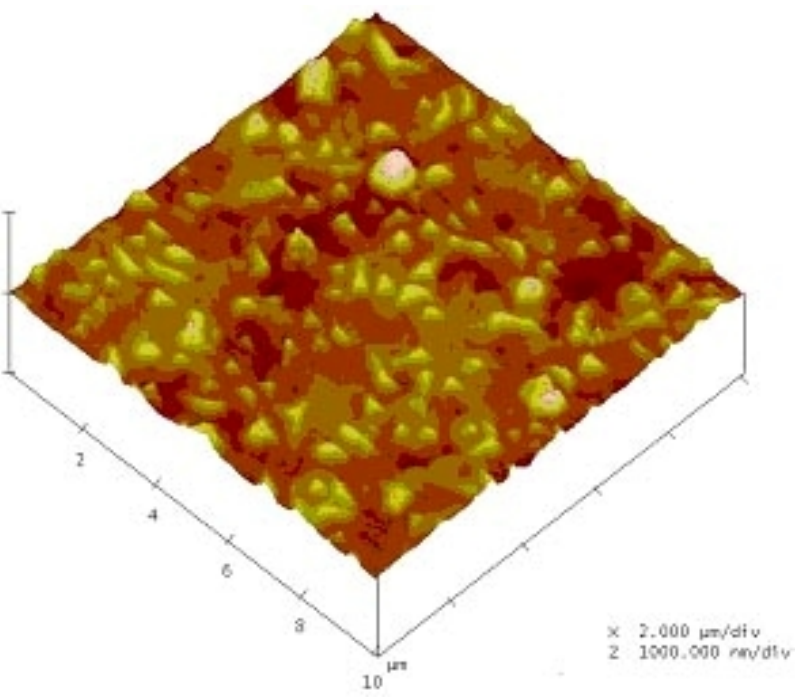

b

$\mathrm{nm}$

Section Analysis
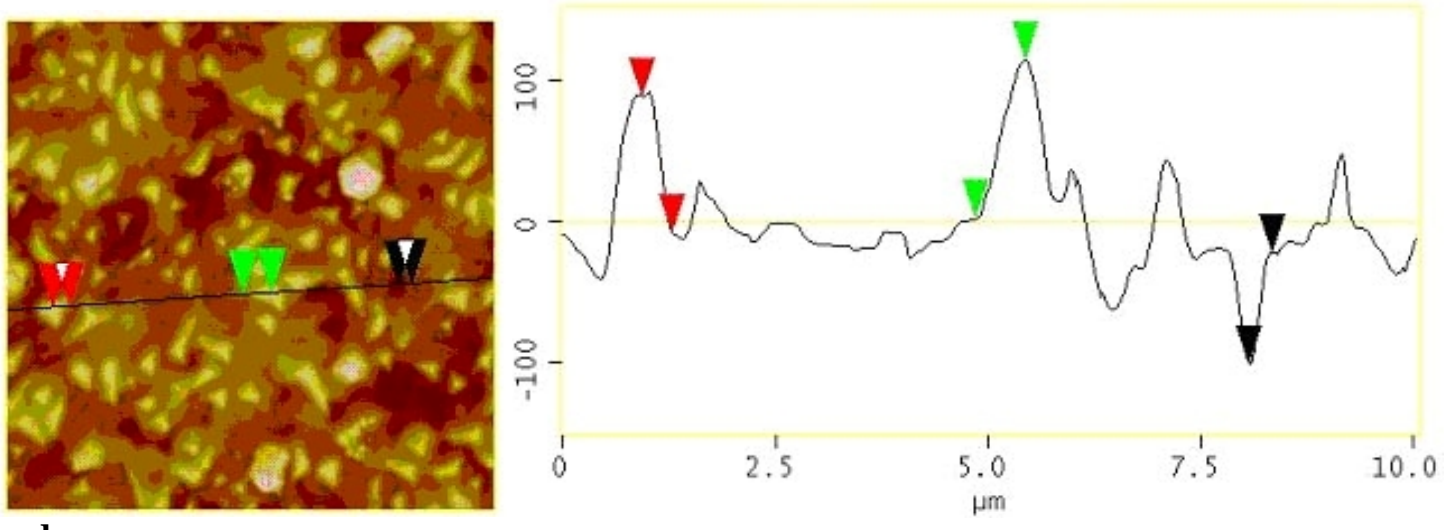

c d

Fig. 2. Titanium film $100 \mathrm{~nm}$ thickness onto leucosapphire which was annealed up to $1600{ }^{\circ} \mathrm{C}$ during $2 \mathrm{~min}$ in vacuum: a -SEM image, x3000; $b$ - three-dimensional AFM images; $c$ - AFM images of intersections on which the film profilogram was measured; $d-$ the film profilogram.

With further exposition at this temperature for $10 \mathrm{~min}$ quite long and wide cracks appear in the film; and, finally, after a twenty min. annealing, film completely disintegrated into large fragments between which significant parts of free leucosapphire surface appear. Annealing at $1500^{\circ} \mathrm{C}$ has speeded up significantly the process of the titanium film disintegration. Thus, after the two-minute annealing, film blistered intensively and lost its integrity; after the five-minute exposition it is cracked significantly; during further exposition time increase up to $10 \mathrm{~min}$, film disintegrated into large fragments (Fig.1c); and after twenty-minutes annealing at this temperature, there were only some film fragments on the leucosapphire surface covering no more than $40 \%$ of it (Fig.1d).With the annealing temperature increase up to $1600^{\circ} \mathrm{C}$, the film began to disintegrate already after a two-minute exposure (Fig.2); further increase of annealing time up to $5 \mathrm{~min}$ led to a complete decomposition of the film covering only about $10 \%$ of the leucosapphire surface which was almost completely free after ten-minutes annealing.

It should be noted that, at all stages of annealing, rounded remains of films were not found which was

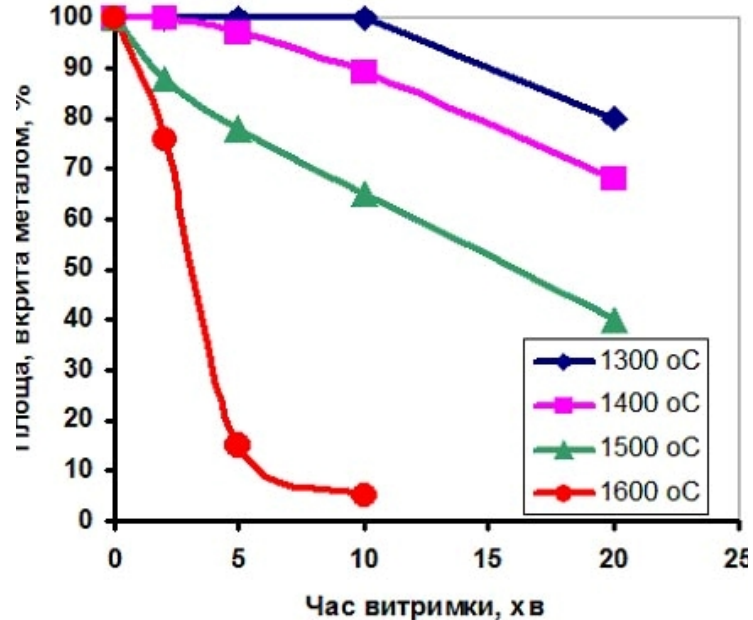

Fig. 3. Leucosapphire area covered by titanium film dependence on annealing time at various temperatures $(1300-1600 \mathrm{C})$. 

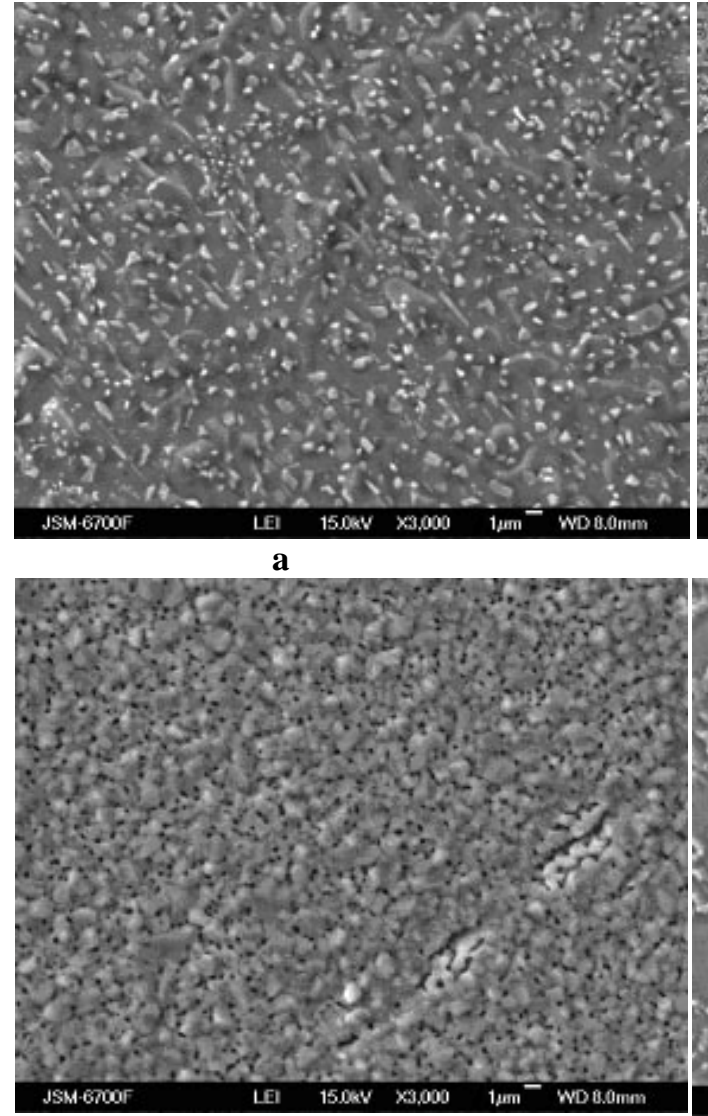

c

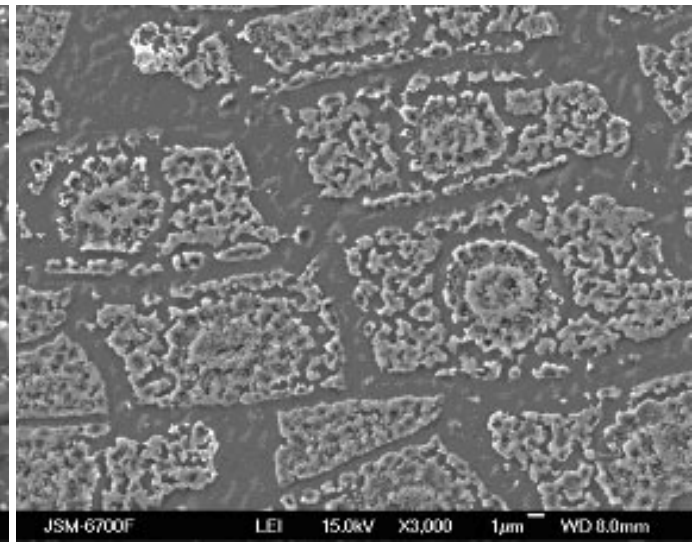

b

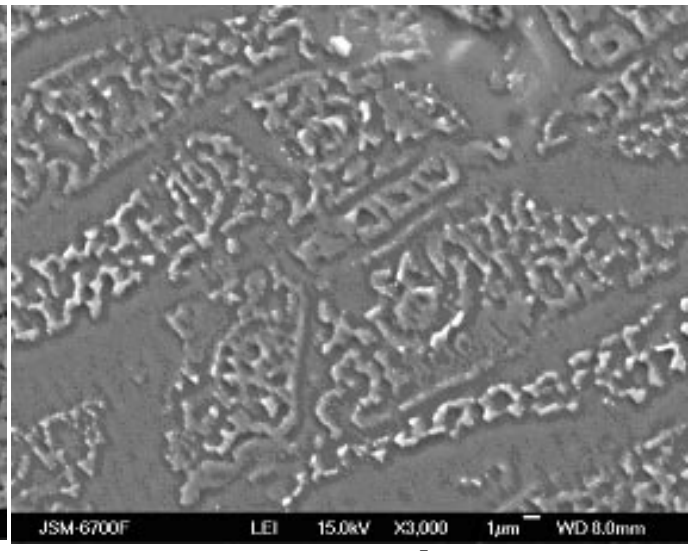

d

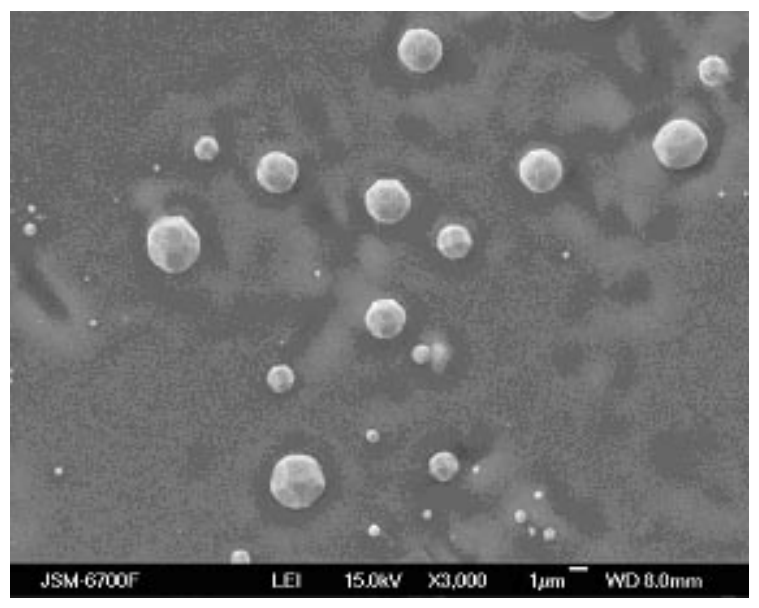

e

Fig. 4. SEM image titanium film $100 \mathrm{~nm}$ thickness onto zirconia which was annealed in vacuum, $\mathrm{x} 3000$ : a $1400{ }^{\circ} \mathrm{C}, 20 \mathrm{~min} ; \mathrm{b}-1500{ }^{\circ} \mathrm{C}, 10 \mathrm{~min} ; \mathrm{c}-1600{ }^{\circ} \mathrm{C}, 2 \mathrm{~min} ; \mathrm{d}-1600^{\circ} \mathrm{C}, 10 \mathrm{~min} ; \mathrm{e}-1600{ }^{\circ} \mathrm{C}, 20 \mathrm{~min}$.

observed by us earlier for disintegration on oxide substrates of metal films which, unlike the titanium, are not adhesively-active metals and does not wet the surface of the non-metallic substrate.

Fig. 3 shows diagrams for kinetics of disintegration of titanium film on the leucosapphire surface during its annealing at different temperatures $\left(1200 \div 1600^{\circ} \mathrm{C}\right)$ with exposition at each temperature from 2 up to 20 minutes.

Continuous titanium film at the zirconium dioxide surface was more refractory then the same film on leucosapphire and remained unchanged even after a twenty-minutes annealing at $1300^{\circ} \mathrm{C}$. Two-minute annealing at $1400{ }^{\circ} \mathrm{C}$ caused also no change in the structure of the film, and only after the five-minutes exposure, the first cracks were observed in it. With increase of annealing time up to ten, and especially up to twenty minutes, the film shows significant changes and starts to lose its integrity (Fig.4a).

Two-minute annealing at $1500^{\circ} \mathrm{C}$ caused significant blistering of the film without losing its integrity; with a further exposition prolongation up to five minutes, the film began to crack and to fragment into pieces; after tenminutes annealing, the film is rapidly divided into large fragments, which in turn were fragmented into smaller particles (Fig.4b). As a result of a twenty-minutes annealing only a small number of pieces of the film of different sizes and irregular shapes were remained. 


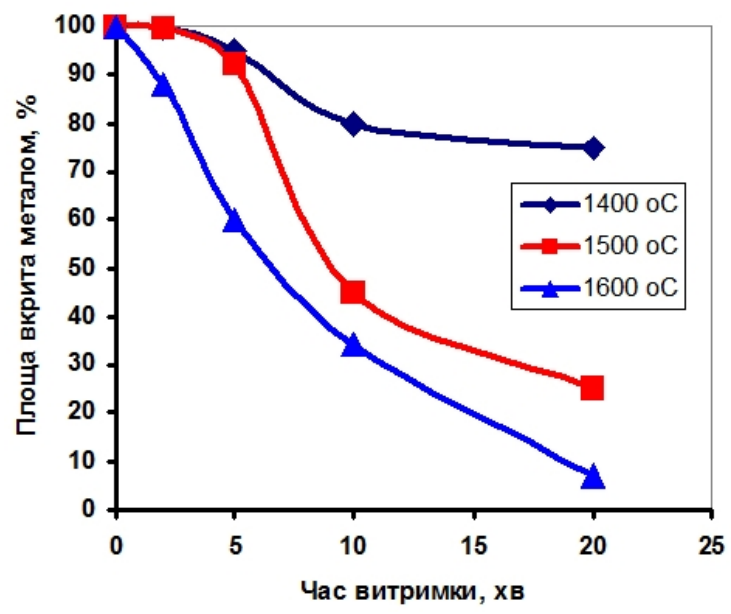

Fig. 5. Zirconia area covered by titanium film dependence on annealing time at various temperatures $\left(1400-1600^{\circ} \mathrm{C}\right)$.

As a result of annealing at $1600{ }^{\circ} \mathrm{C}$, already after the two-minute exposition, all the film was blistered and began to crack (Fig.4c). After five- and ten-minute exposure at $1600^{\circ} \mathrm{C}$ the film was completely disintegrated into small fragments of irregular shape forming conglomerates of various sizes (Fig.4d); and after a twenty-minutes annealing, only some crystals were remained (Fig.4e) which were apparently formed as a result of titanium film particles recrystallization at a temperature equal to $96 \%$ of the melting point of titanium.

Fig. 5 shows diagrams for kinetics of disintegration of titanium film deposited onto zirconium dioxide surface during its annealing at different temperatures within $1400 \div 1600^{\circ} \mathrm{C}$ range with exposition at each temperature from 2 to $20 \mathrm{~min}$.

Annealing of titanium nanofilm at the aluminum nitride surface for twenty minutes at $1300^{\circ} \mathrm{C}$ did not cause any changes. Only when the film is heated up to $1400{ }^{\circ} \mathrm{C}$ during the first two minutes of exposition it began to crack (Fig.6,a), this cracking was intensified after a five-minute annealing, and after ten-minutes exposition the film began to disintegrate into fragments of mostly oblong shape which finally results in complete collapse of the film into individual small pieces of irregular shape after twenty-minutes annealing (Fig.6b).

Two-minutes annealing at $1500{ }^{\circ} \mathrm{C}$ resulted in blistering of the entire film and in the beginning of its cracking; after five-minutes exposion size and number of these cracks were increased; after ten-minutes annealing film was completely disintegrated into separate fragments of irregular shape; and after twenty-minutes annealing the number of these fragments was decreased significantly, and interaction of titanium with aluminum nitride did probably occur (Fig.6c).

As a result of the film annealing at $1600^{\circ} \mathrm{C}$, disintegration of the film and its probable interaction

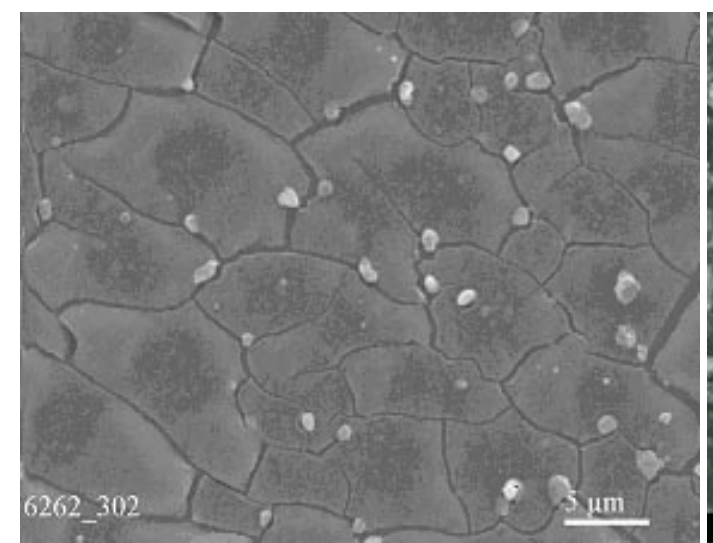

a

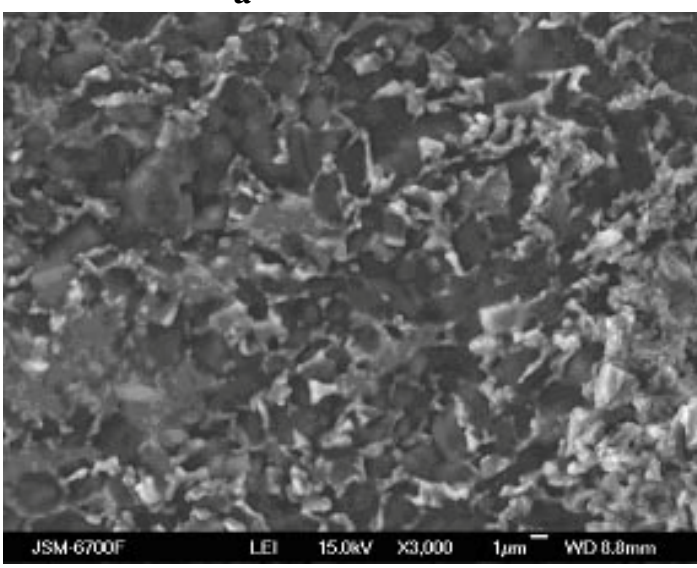

c

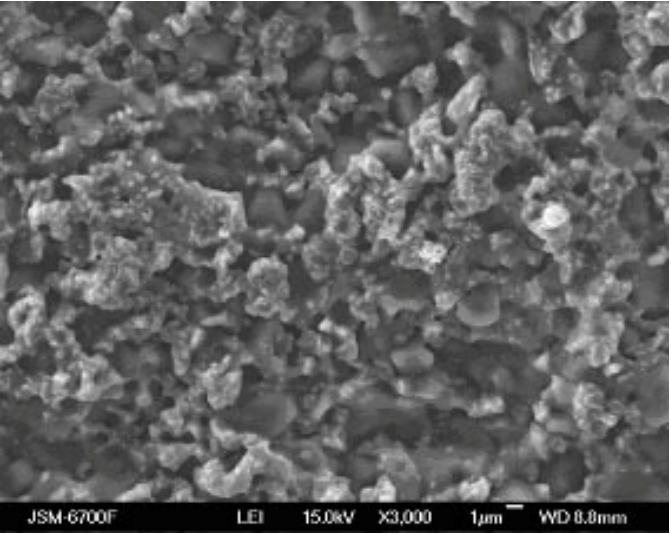

b

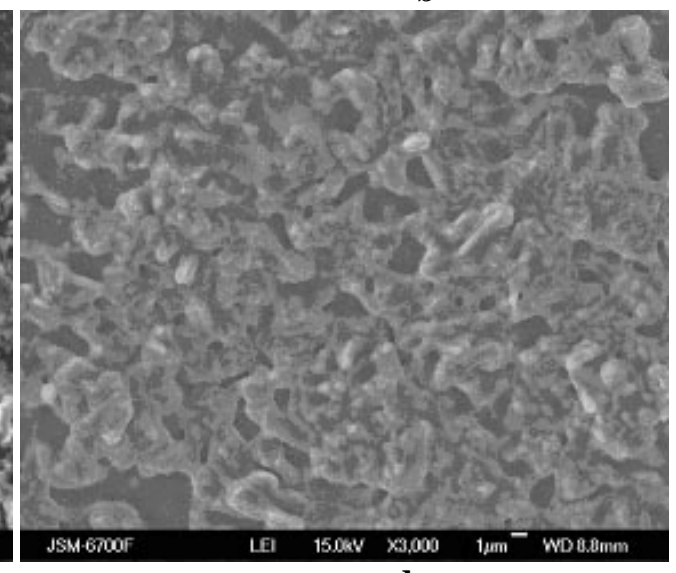

d

Fig. 6. SEM image titanium film $100 \mathrm{~nm}$ thickness onto aluminium nitride which was annealed in vacuum, $\mathrm{x} 3000$ : $\mathrm{a}-1400{ }^{\circ} \mathrm{C}, 2 \mathrm{~min} ; \mathrm{b}-1400{ }^{\circ} \mathrm{C}, 20 \mathrm{~min} ; \mathrm{c}-1500{ }^{\circ} \mathrm{C}, 20 \mathrm{~min} ; \mathrm{d}-1600{ }^{\circ} \mathrm{C}, 2 \mathrm{~min}$. 


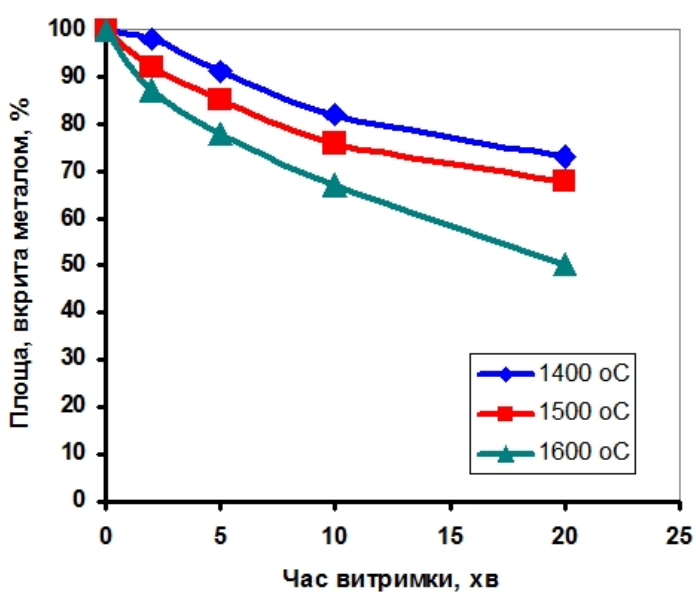

Fig. 7. Aluminium nitride area covered by titanium film dependence on annealing time at various temperatures $\left(1400-1600^{\circ} \mathrm{C}\right)$.

with the aluminum nitride with apparent formation of intermetallic compounds including titanium aluminides took place already after the two-minutes heating (Fig.6d); with further exposition for five and ten minutes the film was not changed significantly; and after twentyminutes exposition, as a result of intensive formation of intermetallides, about $50 \%$ of aluminum nitride surface became already free (Fig.7).

Titanium nanofim deposited onto silicon carbide single crystal surface did also appear to be very refractory: the first appreciable changes in it occurred only after a five-minute annealing at $1400{ }^{\circ} \mathrm{C}$, after tenminutes exposition the film was cracked into large pieces each of which had an irregular shape (Fig.8a); and finally, after a twenty-minutes annealing the film was completely disintegrated into separate pieces.

After a two-minute annealing at $1500{ }^{\circ} \mathrm{C}$ the film was fragmented into large smooth pieces which, with further exposition for five to ten minutes, were disintegrated slowly into smaller pieces (Fig.8b), and the process of disintegration of the film into pieces of oblong shape was finished after a twenty-minutes annealing. Thus, there is a possibility of titanium interaction with
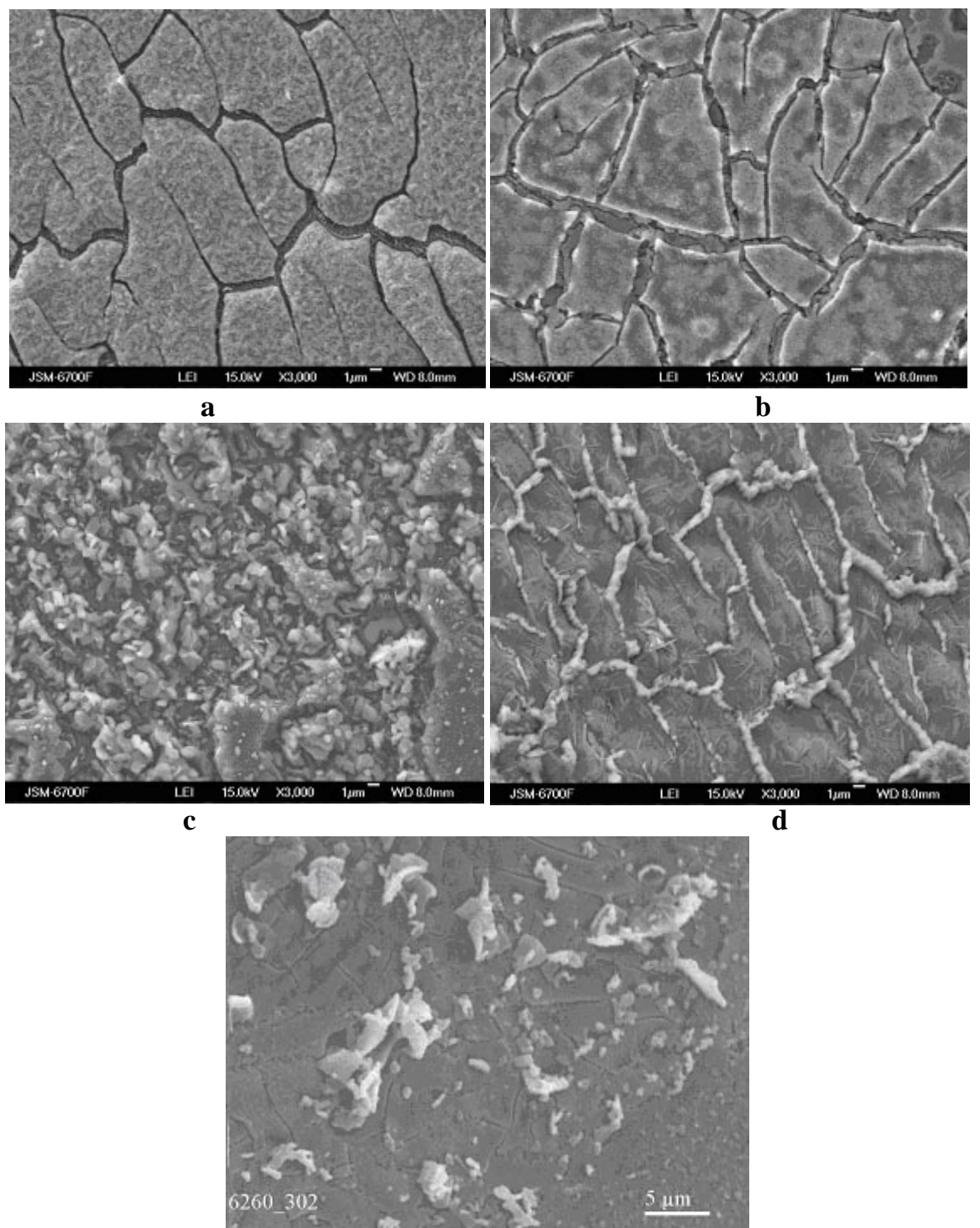

d

e

Fig. 8. SEM image titanium film $100 \mathrm{~nm}$ thickness onto silicon carbide which was annealed in vacuum, $\mathrm{x} 3000$ : a $1400{ }^{\circ} \mathrm{C}, 10 \mathrm{~min} ; \mathrm{b}-1500{ }^{\circ} \mathrm{C}, 10 \mathrm{~min} ; \mathrm{c}-1600{ }^{\circ} \mathrm{C}, 2 \mathrm{~min} ; \mathrm{d}-1600^{\circ} \mathrm{C}, 5 \mathrm{~min} ; \mathrm{e}-1600{ }^{\circ} \mathrm{C}, 20 \mathrm{~min}$. 


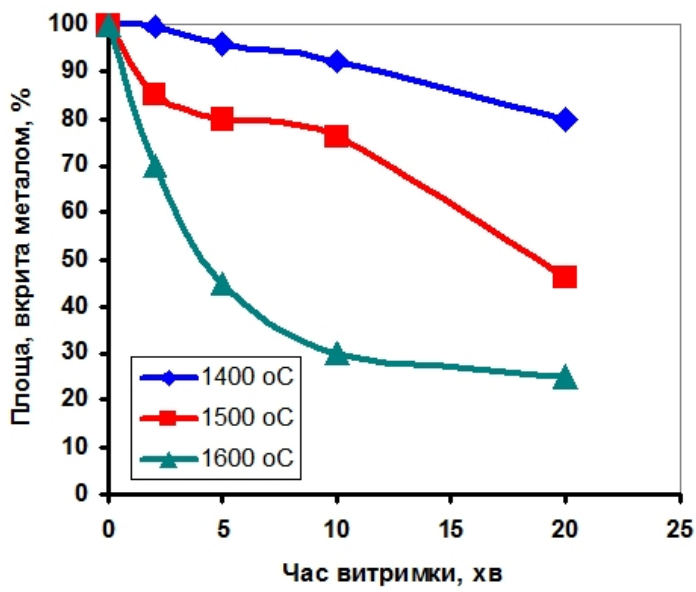

Fig. 9. Silicon carbide area covered by titanium film dependence on annealing time at various temperatures $\left(1400-1600{ }^{\circ} \mathrm{C}\right)$.

the surface of silicon carbide single crystal with the possible formation of titanium carbides and silicides.

With the rise of annealing temperature up to $1600{ }^{\circ} \mathrm{C}$ the film began to split into separate pieces each of which was disintegrated into very small particles in the first two minutes of exposition at this temperature (Fig.8c). After the five-minute exposition the film pieces have already started to interact with silicon carbide (Fig.8d); this interaction intensified with exposition time increase up to $10 \mathrm{~min}$ and after a twenty-minutes annealing the film remains were completely reacted with the surface of silicon carbide single crystal (Fig.8e).

Fig. 9 shows diagrams for kinetics of disintegration of titanium film deposited onto the silicon carbide surface during its annealing at different temperatures $\left(1400 \div 1600^{\circ} \mathrm{C}\right)$ with exposition at each temperature from 2 to $20 \mathrm{~min}$.

\section{Conclusions}

It was found that fragmentation of $100 \mathrm{~nm}$ thick titanium nanofilms deposited onto leucosapphire and zirconium dioxide surfaces is characterized by approximately the same course: during short-time annealing $\left(2-5\right.$ minutes) at $1400{ }^{\circ} \mathrm{C}$ they are still almost continuous; with increase of annealing time at this temperature film disintegration process is intensified although the film fragments cover more than $70 \%$ of the substrate surface even after a twenty-minutes exposition; and, thus, under these conditions the film is quite suitable for use in high-temperature brazing of oxides. With increase of the annealing temperature up to $1600^{\circ} \mathrm{C}$ the film fragmentation rate is growing rapidly. The film disintegrates completely after a ten-minute exposition at this temperature, therefore it is not suitable for brazing.

It was discovered that titanium film at the aluminum nitride surface proved very refractory, and even after a twenty-minutes annealing at $1600{ }^{\circ} \mathrm{C}$ it was still covering more than half of the substrate area which confirms that such a film is quite suitable for high-temperature brazing of this ceramics.

As for the titanium film at the silicon carbide surface, even during annealing above $1400^{\circ} \mathrm{C}$, there were noticeable interaction of the film material with the substrate. This interaction increased rapidly with temperature increase, and thus, brazing of silicon carbide metallized by titanium film can be done only up to $1400^{\circ} \mathrm{C}$.

Using the diagrams resulting from the research data, it is possible to select the necessary temperature and time of brazing of the investigated non-metal materials metallized by titanium nanofilms.

Naydich Y.V. - Dr.Tech.Sci., Academician NAS of Ukraine, head of Dept.;

Hab I.I. -PhD (Tech.Sci.), senior researcher;

Stetsyuk T.V. -researcher;

Kostyuk B.D. -PhD (Che.Sci.), senior researcher.

[1] F.Hafakeyama, K. Suganuma, J. Mater. Sci. 21(7), 2455 (1986).

[2] Yu. V. Naidich, I. I. Gab, B. D. Kostyuk, T. V. Stetsyuk, D. I. Kurkova, S. V. Dukarov. Dopovidi Natsionalnoi akademii nauk Ukrainy 35, 97 (2007).

[3] Ju. V. Najdich, I. I. Gab, B. D. Kostjuk i dr., Adgezija rasplavov i pajka materialov 38, 69 (2005).

[4] G. Elssner, W. Diem, J. S. Wallace, Surfaces and Interfaces Ceram. and Ceram.-Metal Syst. 17 Univ. Conf. Ceram. (New-York - London, 1981), p. 629.

[5] W.X. Pan, T.Okamoto, X.S. Ning, J. Mater. Sci. 29 (6), 1436 (1994).

[6] B.J. Dalgleish, A.P. Tomsia, K. Nakashima et al., Scr. Met. EtMater. 31 (8), 1043 (1994)

[7] Yu. V. Naidich, I. I. Gab, T. V. Stetsyuk, B. D. Kostyuk,E. F. Kuzmenko, Adhiziya rasplavov I paika materialov 45, 71 (2012).

[8] Yu. V. Naidich, I. I. Gab, T. V. Stetsyuk, B. D. Kostyuk, O.S. Lytvin, Svarochnoe proizvodstvo 12, 21 (2013).

[9] S.Metfessel, Tonkie plenki, ih izgotovlenie i izmerenie (Gosenergoizdat, Moskva-Leningrad, 1963).

[10] Yu.V. Naidich, B.D. Kostyuk, G.A. Kolesnichenko et all, Smachivaemost v systeme metallicheskiy rasplav tonkaya metallicheskaya plenka - nemetallicheakaya podlozhka (Naukova dumka, Kiev, 1975). 
Ю.В. Найдіч, I.І. Габ, Т.В. Стецюк, Б.Д. Костюк, Д.Б. Шахнін ${ }^{1}$

\section{Кінетика диспергування при відпалі у вакуумі титанових наноплівок, нанесених на неметалеві матеріали}

Інститут проблем матеріалознавства ім. І.М. Францевича НАН Украйни, вул. Кржижановського, 3, м. Київ, 03142, Україна, е-таil: gab@ipms.kiev.ua

${ }^{1}$ Iнститут органічної та неорганічної хімії ім. В.І. Вернадського НАН Украйни,пр. Палладіна, 32/34, м. Київ, 03142, Україна; e-mail: shakhnin@ukr.net

Наведено результати дослідження кінетики фрагментації наноплівок титану товщиною 100 нм, нанесених на поверхню зразків, отриманих із монокристалів $\mathrm{Al}_{2} \mathrm{O}_{3}$ (лейкосапфіру), $\mathrm{ZrO}_{2}$, $\mathrm{SiC}$ та керамічного AlN, відпалених у вакуумі при температурах $1300 \div 1600{ }^{\circ} \mathrm{C}$ із різними періодами експозиції для кожної температури у межах від 2 до 20 хвилин. 